\title{
Studia
}

SYNCHRONICZNE I DIACHRONICZNE ASPEKTY BADAŃ POLSZCZYZNY

www.wnus.edu.pl/sj | DOI: 10.18276/sj.2019.18-09 | 125-141

\author{
JOANNA RYCHTER
}

ORCID: 0000-0002-5410-5727

Akademia im. Jakuba z Paradyża w Gorzowie Wielkopolskim, Gorzów Wielkopolski jrychter@ajp.edu.pl

\section{[R]ozsądek / wyszedt nam / naprzeciw / szkoda / że nie / spotkaliśmy go / po drodze - językowa kreacja miłości w polskojęzycznych lirykach Stefanii Trochanowskiej}

\author{
Słowa kluczowe \\ idiolekt, Stefania Trochanowska, miłość \\ Keywords \\ idiolect, Stefania Trochanowska, love
}

Literatura łemkowska, w tym poezja współczesna, należy do najmniej zbadanej i poddanej naukowemu oglądowi dziedziny łemkowskiej kultury ${ }^{1}$. Brak jest zwłaszcza opisu twórczości poetów reprezentujących tzw. nurt łemkowskiej autoprezentacji. Helena Duć-Fajfer we wnikliwej analizie nurtów występujących we współczesnej poezji łemkowskiej wyróżnia trzy, wyodrębnione przede wszystkim według kryterium tematycznego, a mianowicie

\footnotetext{
${ }^{1}$ Aspekty literaturoznawcze twórczości łemkowskiej omówiła Helena Duć-Fajfer, „Literatura łemkowska drugiej połowy dziewiętnastego i początku dwudziestego wieku”, Prace Komisji Wschodnioeuropejskiej PAU, VII (2001); taż, Pomiędzy bukwa a litera. Współczesna literatura mniejszości białoruskiej, ukraińskiej i temkowskiej w Polsce (Kraków: Wydawnictwo Uniwersytetu Jagiellońskiego, 2012), 350; taż, „Literatura łemkowska - zagadnienia badawcze”, Prace Komisji Wschodnioeuropejskiej PAU, V (1997), 87-98; taż, „Mniejszościowa wizja miejsca swej grupy w społeczeństwie polskim na podstawie twórczości literackiej Łemków", Przegląd Polonijny, 3 (1998): 137-157. Przyczynkarski artykuł poświęcił jej Zbigniew Siatkowski, „Współczesna poezja Łemków - formowanie się pokolenia literackiego”, Загорода, 2/3 (1994): 48-54.
} 
stosunku do łemkowskiej tradycji i współczesności: ludowy, tęsknoty za utraconym oraz łemkowskiej autoprezentacji. Zbigniew Siatkowski podkreśla również eklektyzm twórczości Pawła Stefanowskiego, Petra Murianki, Stefanii Trochanowskiej, Władysława Grabana i Heleny Duć na tle innych poetów łemkowskich².

Stefania Trochanowska wyróżnia się spośród pozostałych pisarzy jej pokolenia literackiego. Pisze wiersze pełne kobiecego ciepła, refleksji i zadumy, choć podobnie jak pozostali łemkowscy poeci odzwierciedla w swojej twórczości przywiązanie do ziemi przodków, tradycji i kultury. Urodziła się 26 czerwca 1951 roku w Miroszewicach na Dolnym Śląsku. Jej rodzice pochodzili ze wsi Ropki na Łemkowszczyźnie. Ukończyła technikum rolnicze. W 1969 roku z mężem Jarosławem, założycielem i dyrygentem Zespołu Pieśni i Tańca „Łemkowyna”, powróciła w ojczyste góry do miejscowości Bielanka. Przez cały okres funkcjonowania zespołu Trochanowska zajmowała się jego zapleczem organizacyjnym. Debiutowała na łamach „Gołosu Watry” - pierwszego powojennego pisma łemkowskiego - w 1983 roku, a w 1984 wydała pierwszy tomik poetycki Potem, teraz, przedtem (Nowy Sącz). Kolejne to: Nie pozwól uschnać kwiatom (Kraków 1991), Motyle (Warszawa 1994) oraz Wierbina (Warszawa 1993) ${ }^{3}$.

Przedmiotem analizy w niniejszym artykule uczyniono 113 polskojęzycznych wierszy Stefanii Trochanowskiej, pochodzących z trzech tomików: Potem, teraz, przedtem ${ }^{4}$ (liczącego 14 liryków), Nie pozwól uschnać kwiatom ${ }^{5}$ (liczącego 61 wierszy) i Motyle ${ }^{6}$ (liczącego 38 liryków).

Stworzone przez poetkę liryki to miniatury poetyckie, wykazujące aforystyczną zwięzłość, służącą wyrażeniu doznań osobistych, formułowaniu cząstkowych lub uniwersalnych prawd o życiu i świecie. Swym refleksjom autorka nadała kształt możliwie najkrótszy, eliminując wszelkie czynniki językowo-stylistyczne, niekonieczne dla projektowanego przekazu myśli. Trochanowska całkowicie eliminuje interpunkcję, prawie nie stosuje wielkich liter. W jej wierszach funkcja delimitacyjna wyłania się na plan pierwszy, graficznie wyrażony podział na wersy oddaje wagę zastosowanych leksemów i wyznacza dalszą płaszczyznę interpretacyjną, np. poprzez rozbijanie spójnych związków składniowych między dwa wersy i wyprowadzenie nowych znaczeń. Poetka oszczędnie operuje środkami leksykalno-stylistycznymi. W jej lirykach brak synonimów, każde słowo jest na tyle znaczące, że nie da się zastąpić go innym, nie trzeba też go dookreślać. Z wielkim rozmysłem stosuje figury stylistyczne, operuje nielicznymi peryfrazami (np. czas upadku i uniesienia 'noc'

\footnotetext{
${ }^{2}$ Siatkowski, Wspótczesna poezja Łemków, 48-54.

${ }^{3}$ Duć-Fajfer, Pomiędzy bukwa a litera, 324.

${ }^{4}$ Stefania Trochanowska, Potem, teraz, przedtem (Nowy Sącz: Sądecka Oficyna Wydawnicza Wojewódzkiego Ośrodka Kultury w Nowym Sączu, 1984), dalej: skrót P i nr strony. Tomik zawiera trzy liryki w etnolekcie łemkowskim, które nie są przedmiotem analizy w niniejszym artykule.

${ }^{5}$ Stefania Trochanowska, Nie pozwól uschnąc kwiatom (Kraków: OL Kraków, wydane nakładem autorki, 1991), dalej: skrót N i nr strony.

${ }^{6}$ Stefania Trochanowska, Motyle (Warszawa: Zjednoczenie Łemków, 1994), dalej: skrót M i nr strony.
} 
M, 9; latarnia ponad chmurami 'księżyc' M, 9; rajskie owoce ‘jabłka’ M, 13; najtańszy dom pod stońcem 'parasol' M, 5) i metaforami, przede wszystkim wizualnymi, choć podkreślić należy, iż są one niewyszukane i każdy czytelnik jest w stanie dokonać ich deszyfracji. $\mathrm{W}$ analizowanych tomikach pojawiają się pytania retoryczne, niezakończone - zgodnie z zastosowaną zasadą nieużywania znaków interpunkcyjnych - pytajnikiem: dokad pędzę (M, 3), co zrobia / z wielka mitościa (N, 25), oksymoroniczne frazy, zwroty: i choć / ide już / to jednak / zostaję (M, 9) czy: mówiteś milcząc (P, 6), przed chwila / tu byteś / a zupetnie / jakby cię / jeszcze / nie byto (N, 15).

W obrębie zbiorków brak wskaźników mówiących o łemkowskim pochodzeniu autorki, subtelnym sygnałem jest leksem ikona 'w sztuce bizantyjskiej i wschodniochrześcijańskiej: obraz o tematyce religijnej, wyobrażający zwykle jakąś postać albo jakąś scenę biblijną lub liturgiczno-symboliczną' (SJPSz I/771), zastosowany w wierszu Szczęście: moje / szczęście / przechowuję / w ikonie (M, 5) czy Odkrycie: z ikonami / na każdej ścianie (N, 15) lub pełna korespondencja pomiędzy człowiekiem a naturą, widoczna np. w wierszu Zuchwalstwo ${ }^{8}$.

Uczucie miłości to przewodni motyw trzech omawianych tomików Trochanowskiej, co oddaje chociażby tytuł trzeciego z nich - Motyle ${ }^{9}$, pochodzący od motywu zastosowanego w przedostatnim wierszu. Motyl w kulturze symbolizuje m.in. coś krótkotrwałego, miłość. Franciszek Sławski stwierdza: „Dzisiaj miłość oznacza: 'pełne poświęcenia i dobroci oddanie się komuś (czemuś)', 'gorące, namiętne uczucie', 'gorące, głębokie przywiązanie do kogo lub czego', 'gorące upodobanie w kimś, czymś' ('amor, carita, ietas')"10. Kazimierz Ożóg uogólnia, iż „miłość jest wartością, a więc odsyła do kategorii dobra. Najszersza definicja miłości winna zakładać, że jest to relacja między osobami, które chcą siebie obdarzać dobrem"11. Celem artykułu jest omówienie środków leksykalno-stylistycznych zastosowanych przez Trochanowską do wykreowania uczucia miłości w polskojęzycznej twórczości lirycznej.

Sposób przedstawiania miłości w analizowanych wierszach poetki zostanie ukazany według metodologii autorstwa Iwony Nowakowskiej-Kempny ${ }^{12}$, która proponuje, by języ-

\footnotetext{
${ }^{7}$ Mieczysław Szymczak, Słownik języka polskiego, t. I-III (Warszawa: PWN, 1983-1985).

${ }^{8}$ Pełną korespondencję pomiędzy Łemkami a przyrodą opisałam w: Joanna Rychter, ,[K]orzeni szukam pradziadów / co oplataja trzewia ziemi - językowa kreacja małej ojczyzny w tomiku $Z$ ziemi do nieba Władysława Grabana", Studia Językoznawcze. Synchroniczne i diachroniczne aspekty badań polszczyzny, 17 (2018), 271-289; taż, „Boże... / czemu nas opuściłeś - odwołania religijne w tomie wierszy Z ziemi do nieba Władysława Grabana", Poznańskie Studia Polonistyczne. Seria Językoznawcza 25 (2018), 45: $167-180$.

${ }^{9}$ Motyla jako symbol miłości opisuje Władysław Kopaliński, Słownik symboli (Warszawa: Oficyna Wydawnicza RYTM, 2001), 234-235.

${ }^{10}$ Franciszek Sławski, „Miły, miłość”, Język Polski 53 (2000), 1-2: 1-9.

${ }^{11}$ Kazimierz Ożóg, „Leksem «miłość». Rozważania semantyczne i kulturowe”, w: Od miłości do nienawiści. Językowe mechanizmy kreowania emocji, red. Wioletta Kochmańska, Bożena Taras (Rzeszów: Wydawnictwo Uniwersytetu Rzeszowskiego, 2010), 11.

${ }^{12}$ Iwona Nowakowska-Kempna, Konceptualizacja uczuć w języku polskim (Warszawa: Wydawnictwo SORUS, 1995), 15.
} 
kowy obraz danego uczucia rekonstruować poprzez omówienie następujących kategorii semantycznych:

1. nazywanie uczuć, np. smutek, ̇̇al, przykrość;

2. nazywanie objawów uczuć, np. zzieleniat, poczerwieniat, pobladt, zmarszczyt brwi itp.;

3. nazywanie działań i zachowań związanych z uczuciami, np. płakał ze szczesścia, wrzeszczał z wściekłości, tańczył z radości, z możliwością charakterystyki uczuć za ich pomocą;

4. nazywanie przeżyć-doznań związanych z danym uczuciem dokonywanych z punktu widzenia experiencera, tj. tego, co czuję, co doznaję, kiedy przeżywam dane uczucie ${ }^{13}$.

Zaproponowaną klasyfikację w niniejszym szkicu uzupełniono o nazwy osób przeżywających dane uczucie, w naszym wypadku miłość, co jest zgodne ze stratyfikacją zastosowaną przez Teresę Skubalankę, badającą słownictwo poezji miłosnej w twórczości Juliusza Słowackiego ${ }^{14}$, czy Danutę Bieńkowską, omawiającą język listów miłosnych Stanisława Władysława Reymonta ${ }^{15}$.

\section{Nazywanie miłości}

Ogólnopolski neutralny semantycznie leksem miłośćl ${ }^{16} \mathrm{~W}$ analizowanych lirykach pojawił się sześciokrotnie w następujących cytatach: milość / $i$ śmierć / trzymaja się / za ręce / (M, 11), i milość / dojrzewa / nabierając / smaku / rajskich / owoców (M, 13), Bóg / rozdaje / miłość / za darmo (M, 14), cała miłość / wziąt / w swoje ramiona (N, 5), co zrobia / z wielka miłościa / której brak / zwyktym ludziom (N, 25), cała milość / pozostała za drzwiami (N, 28). Leksem miłość współtworzy figury stylistyczne, np. personifikacje, wykonując

\footnotetext{
13 Tamże.

${ }^{14}$ Teresa Skubalanka, Słownictwo poezji miłosnej Juliusza Słowackiego na tle tradycji (Toruń: Wydawnictwo Uniwersytetu Mikołaja Kopernika, 1966), 247.

${ }^{15}$ Danuta Bieńkowska, Między konwenansami a autentyzmem uczuć, czyli Reymontowska pieśń na cześć miłości, w: Ścieżkami pięknej polszczyzny. Księga jubileuszowa dedykowana Profesor Mirosławie Białoskórskiej z okazji 65-lecia urodzin i 45-lecia pracy zawodowej, red. Leonarda Mariak, Adrianna Seniów (Szczecin: volumina.pl, 2011), 29-38.

${ }^{16}$ Miłość 'głębokie uczucie do drugiej osoby, połączone zwykle z silnym pragnieniem stałego obcowania z nią i chęcią obdarzenia jej szczęściem, któremu (głównie w relacji kobieta-mężczyzna) towarzyszy pociąg fizyczny do osoby będącej obiektem tego uczucia; silne przywiązanie do kogoś; gotowość do bezinteresownego oddania się, służenia komuś'. Bogusław Dunaj, red., Słownik współczesnego języka polskiego, t. I-V (Kraków: Wydawnictwo SMS, 2000), dalej: SWJP (tu: t. II, 453).
} 
czynność trzymania się za ręce czy pozostawania za drzwiami, oraz metaforę dojrzewa. Raz poetka zastosowała hiperonim uczucie $^{17}$ (M, 11).

Szereg synonimiczny nazw uczucia miłości dopełnia czasownik kochać18 o trzech wystąpieniach tekstowych: kocha się / naprawdę / raz / reszty / nie trzeba $(\mathrm{M}, 6)$; kochać / czcić / bezcześcić (M, 6), Ci / którym kochać / nie wolno (N, 25) oraz rzeczownik odczasownikowy kochanie $(\mathrm{N}, 12)$. Za niepełne synonimy leksemu kochać uznać należy czasowniki czcić i bezcześcić oraz rzeczownik grzech. Leksem czcić19 oddaje miłość platoniczną, zaś bezcześcicic ${ }^{20}$ zmysłowa. Grzech ${ }^{21}$ również sygnalizuje zmysłowe oblicze miłości: grzechy / byty odpuszczone przedtem / w chwili pojednania (N, 27), wolne / od grzechów posłanie (N, 29), kiedy modlitwa / łączy się z grzechem (N, 30). Synonimem niepełnym jest również leksem radość: mamy radość / na chwile (N, 11). Szereg dopełnia peryfraza sprawa uczuciowa 'miłość' (N, 12), poza tym metonimiczne, peryfrastyczne określenie $\boldsymbol{u p a d e}^{22}$ i uniesienie 23 'miłość' $(\mathrm{M}, 9)$ - leksem pierwszy sugeruje czyn niemoralny, zaś drugi implikuje obecność czynu ekstatycznego. Oba wyrazy posiadają wspólną przyczynę, zarówno upadek, jak i uniesienie są wynikiem uczucia miłości, z jednej strony popychającego do łamania norm społecznych, z drugiej - będącego źródłem ekstazy. Ponieważ oba leksemy są użyte, by wykreować peryfrazę nazwy noc, wydaje się, iż czas upadku i uniesienia jest tożsamy, czego dowodzi połączenie obu leksemów współrzędnym łącznym spójnikiem ,i”’ Za pomocą minimalnej liczby słów poetka opisuje cielesną miłość prowadzącą ku ekstatycznym doznaniom:

\author{
noc \\ czas upadku \\ i uniesienia $(\mathrm{M}, 9)$
}

O konsekwencjach miłości prowadzących do uniesienia dowiadujemy się z kolejnego cytatu: pozostali / w ekstazie / zachwytu $(\mathrm{N}, 22)$.

\footnotetext{
${ }^{17}$ Uczucie 'stan psychiczny: reakcja na napływające z zewnątrz bodźce; emocja' (SWJP, t. V, 1169).

${ }^{18}$ Kochać 'darzyć kogoś lub coś bezinteresowną miłością, być do kogoś lub czegoś bardzo przywiązanym; miłować, lubić' (SWJP, t. II, 232).

${ }^{19}$ Czcić 'okazywać komuś szczególny szacunek, cześć, przywiązanie; wyrażać uznanie, uwielbienie itp.' (SWJP, t. I, 230).

${ }^{20}$ Bezcześcić 'znieważać coś, co zwykle otoczone jest szacunkiem, czcią; profanować' (SWJP, t. I, 78).

${ }^{21}$ Grzech 'czyn łamiący jakieś zasady; uchybienie' (SWJP, t. I, 80).

${ }^{22}$ Upadek 'nieuczciwe, niemoralne życie, postępowanie; gorszący, nieetyczny czyn, postępek' (SWJP, t. $\mathrm{V}, 125)$.

${ }^{23}$ Uniesienie 'stan wzmożonej aktywności uczuciowej, zachwytu, radości, zapału, wzburzenia, gniewu; poryw, ekstaza, pasja, szał’ (SWJP, t. V, 122).
} 
Synonimicznymi zastępnikami leksemu kochać się czyni łemkowska poetka grupy werbalne - mieć siebie ${ }^{24}$ : znów / będziemy / mieć / siebie (M, 13), być z kimś: będę z Toba $(\mathrm{N}, 32)$ czy dwukrotnie odnaleźć siebie 'pokochać się' - odnaleźliśmy siebie (N, 3), bezbłędnie / odnaleźli / siebie / błądząc (N, 22).

Repertuar synonimów wykorzystanych do nazwania miłości dopełniają środki stylistyczne, w tym metafora szukać lata w zimie (M, 12), w której poetka wykorzystuje konotacje antonimów lato-zima. Lato przywołuje skojarzenie z gorącem, rozkwitem, zaś zima z chłodem, zamieraniem. Lato jest metaforą gorącego uczucia miłości, zaś zima okresu pozbawionego uczuć:

ręce
które
przedtem
szukaty
lata
w zimie $(\mathrm{M}, 12)$

Ten typ obrazowania wystąpił w liryce miłosnej. Jego egzemplifikację można spotkać w twórczości Agnieszki Osieckiej, gdzie lato jest metonimią dojrzałej, trwałej miłości w porównaniach: Mogłaś być jak środek lata, / a byłaś jak zapałka, (Bywa, że miłość..., 165)25; aż tu nagle w samym środku lata / powiedziałeś: / Gorzko, gorzko mi! (Gorzko mi, 281) ${ }^{26}$.

Znajdujemy liryki, w których nie pada leksem miłość ani jego synonimy. To uczucie obrazuje poetka, wykorzystując metaforyczne obrazy zastępcze z użyciem ogólnokulturowych symboli tego uczucia. W tym celu przywołuje serce 'siedlisko uczuć, w tym miłości' oraz metaforykę ognia. Podkreślić należy, iż dokonuje się tutaj swoista hierarchizacja uczucia, a więc serce jest gorące niczym wulkan:
serce
wulkan
rzuca
ogniem
rozrywa
po drodze
wszystko
można się
przy nim

\footnotetext{
${ }^{24}$ Mieć kogo ‘być kimś wobec osoby określonej jako podmiot’. Stanisław Skorupka, Stownik frazeologiczny języka polskiego, t. I (Warszawa: Wiedza Powszechna, 1967), 436.

${ }^{25}$ Agnieszka Osiecka, Najpiękniejsze wiersze i piosenki (Warszawa: Prószyński i S-ka, 2016), 165.

${ }^{26}$ Tamże, 281.
} 


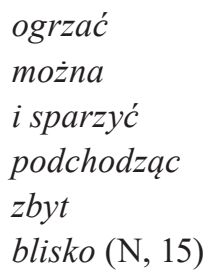

Ponownie w kolejnym liryku zastępczy obraz zabierania czyjegoś serca oznacza zakochanie/miłość: zabrać dla siebie / całe serce / to bezczelność (N, 23).

\section{Nazywanie objawów uczuć}

Fizycznym objawem miłości czyni Trochanowska rumieniec ${ }^{27}$, oddający zmysłowy aspekt uczucia:

nasze
zuchwalstwo
przyprawiło
o rumieńce
kwiaty
za późno
zostały
zauważone $(\mathrm{M}, 7)$

Jak zauważa Teresa Skubalanka, już „w XVII w. poeci często zwracali uwagę na ognie w twarzy palące kochanka [...] - mimo że z czasem wyrugowano tego rodzaju koncepty, stałość styczności semantycznej pozostała. Rumieniec pełnił funkcję nieodłącznego atrybutu stanu zakochania"28. U Trochanowskiej rumieniec zostaje przeniesiony z ludzkich policzków na niedookreślone gatunkowo kwiaty, co może implikować siłę obrazowanego uczucia. Tę płaszczyznę interpretacyjną wspiera zastosowany na określenie miłosnych igraszek leksem zuchwalstwo ${ }^{29}$, który można zdefiniować jako 'zbyt odważne, namiętne zachowanie w przestrzeni publicznej'.

Rumieniec po raz wtóry pojawia się w liryku Listek, gdzie również znajdujemy metaforyczny, zastępczy obraz miłości cielesnej, implikowany przez pozbawienie rumieńców oraz leksem nagość:

${ }^{27}$ Rumieniec 'miejscowe zaczerwienienie twarzy, zwłaszcza policzków, właściwe komuś lub powstałe na skutek jakichś emocji; gorączki itp.' (SWJP, t. IV, 248). Por. Jerzy Bartmiński, „Jaś koniki poit. Uwagi o stylu erotyku ludowego", Teksty, 2 (1974).

${ }^{28}$ Skubalanka, Stownictwo poezji mitosnej, 247.

${ }^{29}$ Zuchwalstwo 'zuchwałe zachowanie, zuchwały czyn, postępek' (SWJP, t. V, 435). 


ostatni
listek
spadt
pozbawiony
rumieńców
nagość
też
maswoje
prawa $(\mathrm{M}, 13)$

Podkreślić należy, że w polskich tekstach ludowych występuje erotyczny „złożony symbol zdarzeniowy" (określenie za J. Bartmińskim), np. wrona jajko wypiła oznacza dziewczynę, która straciła rumieniec, czyli pozbyła się dziewiczego wstydu, straciła cnotę ${ }^{30}$. Kontekst w liryku Trochanowskiej jest tak lapidarny i wieloznaczny, że można również wyprowadzić równoległą interpretację - równie prawdopodobną - iż poetka opisuje jesień. Niemniej jednak pierwszą płaszczyznę interpretacyjną wspiera umieszczenie wiersza w otoczeniu innych liryków, mówiących o miłości dojrzewającej (***słowa M, 13) i jej poszukiwaniu (Znów M, 13).

Fizycznym objawem uczucia miłości są dreszcze, zbladnięcie, choć podkreślić należy, iż poetka proces utraty barw przenosi z osoby zakochanej na jej otoczenie: z pustki / wynurzyły się dreszcze / wszystko zbladto dokoła (N, 31) oraz drżenie: i drżysz i pędzisz (P, 18), drżysz / znów (N, 11).

Somatycznym wyznacznikiem uczucia miłości czyni poetka tłumiony oddech (P, 6), który prowadzi do nietypowych, wręcz chorobliwych objawów w liryku Ucieczka:

\section{tlumiony oddech się pocit}

mylit słowa z myślami $(\mathrm{P}, 6)$

W wierszu Niepewność wśród objawów miłości znajdujemy ponownie rumieńce, ale uzupełnione melancholią i brakiem apetytu:

\section{masz nostalgię i brak apetytu \\ a na dodatek rumieńce \\ mnie $(\mathrm{P}, 18)$}

Kolejną cielesną oznaką miłości jest bezsenność, która mija po odkochaniu się:

możesz już spać spokojnie

wyszłam z Twoich snów (N, 15)

cisza zapomnienia $(\mathrm{N}, 25)$

\footnotetext{
30 Joanna Szadura, „Dlaczego wrona jest czarna?”, Twórczość Ludowa, 2/3 (1995), 20-24.
} 


\section{Nazywanie działań i zachowań związanych z miłością}

Działania i zachowania związane z miłością oddaje Trochanowska za pomocą licznych form werbalnych: czekać, dochodzić, dotykać, mówić, omijać, psocić, podawać, przywołać, szukać, tańczyć/zatańczyć, trzymać się, uciekać, unikajac, wierzyć, wrócić, wybaczać, wychodzić, wyczerpać, wymawiać, zamykać, zebrać, zerwać, zostawać.

Miłość opisuje poetka poprzez czynność szukania: to szukać / twoich / ust / rak / ciebie (M, 13), szukam ciebie (M, 9), czekania: to czekać / i wierzyć / (M, 13), uciekania/unikania: uciekamy od siebie (N, 14), komu / zrobimy na złość / unikając siebie (N, 14), omijamy nasze domy 'unikamy miłości’ (N, 14), zamykamy na klucz / uczucia $(\mathrm{N}, 14)$ lub powracania: wróciliśmy / z krainy marzeń (N, 8), a nawet błądzenia: tak dawno / nie bładziliśmy / ulicami (N, 23), wychodzac Ci naprzeciw / zbladzilam (N, 25), bladzac / po iglicy / szczytu / nie potrafili / zejść / na ziemię (N, 22), znajdowania: doszliśmy (N, 8), i w końcu trwania lub zerwania: kto zerwie $(\mathrm{N}, 12)$, jednak zostaję $(\mathrm{M}, 9)$, trwajmy tak jeszcze (N, 31).

Kolejne czasowniki oddają bliski fizyczny kontakt: znów / dotykasz mych ust (N, 11), trzymają się za ręce (M, 11), ramię mi podajesz ( $\mathrm{P}, 18)$.

Trzecią grupę stanowią formy werbalne oddające wagę komunikowania się pomiędzy osobami kochającymi się: wyczerpateś limit stów (N, 21), przywolujesz moje imię (N, 24), wyraźniej je wymawiasz [moje imię - J.R.] (N, 24), wieczór / [...] / o jedna / rozmowę / dtuższy / i kilka kroków / (N, 9), nikt nie będzie wyl / do księżyca (N, 28), wycie było głośne ostatnio / przeważnie / na dwa głosy (N, 28), tak dużo / mam Ci do powiedzenia (N, 28), mów do mnie / albo nie mów nic (N, 31), tak dawno / nie rozmawiateś / o motylach (N, 23), kochanie / szkoda że mnie nie styszysz (N, 28). Poetka podkreśla istotną rolę słów w budowaniu miłosnej relacji między kochankami. By ją uwypuklić, używa metaforycznego obrazu zbudowanego na bazie przeniesionego znaczenia czasownika kwitnać:

słowa
niech
kwitna
dalej $(\mathrm{M}, 13)$

Słowa będące odzwierciedleniem nieporozumień w związku autorka nominuje kazaniem: kazanie / o trzeciej / nad ranem (N, 27).

Zastosowane czasowniki sugerują, iż miłość obrazowana przez łemkowską poetkę ma nieszczęśliwe oblicze, to czas samotności (szukam, czekam), oczekiwania/pragnienia (wierzę, bąźmy znów sami na śniegu $\mathrm{P}, 6$ ), trudnych wyborów (zostaję, nie moge już wrócić P, 6), nieporozumień (już dawniej mówiteś milcząc $\mathrm{P}, 6$; wybacz $\mathrm{P}, 6$ ) oraz niekiedy szczęśliwych momentów (trzymają się, ze mna tańczyłeś, zatańczymy noca / przy blasku świec $\mathrm{N}, 4$; dochodzę N, 3; psocić tė 'metaforyczna nazwa doznań kochanków' N, 4; minęty już niepokoje 'nieporozumienia' $\mathrm{N}, 26$ ). 
Poza tym działania i zachowania osób kochających poetka oddaje, szkicując wygląd otoczenia. Dość enigmatyczny obraz rozrzuconych rzeczy po mieszkaniu to skutek erotycznych zachowań zakochanych, a pozytywny wydźwięk akcentuje przysłówek wspaniale: rozrzucone wszystko / byle jak / wspaniale $(\mathrm{N}, 29)$, rzeczy rozrzucone / po mieszkaniu $(\mathrm{N}, 31)$.

\section{Nazywanie przeżyć-doznań}

Raz pojawia się nazwa obrazująca uczucie miłości z punktu widzenia experiencera za pomocą czasownika tęsknić31 ${ }^{3}$ użytego dwukrotnie $(2 \times \mathrm{M}, 13)$ :

$$
\begin{aligned}
& \text { tęsknić } \\
& \text { to szukać } \\
& \text { twoich } \\
& \text { ust } \\
& \text { tęsknić } \\
& \text { to czekać } \\
& \text { i wierzyć }
\end{aligned}
$$

Trochanowska redefiniuje leksem tęsknić poprzez przywołanie innych działan - szukanie twoich ust oraz czekanie i wierzenie. Zbyt lakoniczny kontekst nie pozwala na sformułowanie odpowiedzi, z jak długo trwającym rozstaniem boryka się experiencer ani jakie są jego przyczyny.

Poetka obrazuje uczucia związane z brakiem fizycznego kontaktu z osobą kochaną po raz wtóry w liryku ***telefon. Czyni to, nie używając czasowników nazywających przeżycia-doznania, lecz z udziałem peryfrastycznego określenia nazwy telefon:

$$
\begin{aligned}
& \text { telefon } \\
& \text { nagroda } \\
& \text { pocieszenia } \\
& \text { za nieobecność }(\mathrm{M}, 4)
\end{aligned}
$$

Powyższa peryfraza oddaje explicite, że kontakt telefoniczny nie zaspokaja potrzeb osoby kochającej/experiencera, i implicite wskazuje na pokłady uczuć związane z tą sytuacją:

\footnotetext{
31 Tęsknić 'odczuwać żal, cierpienie z powodu czyjejś nieobecności, braku kontakt z kimś lub czymś; bardzo pragnąć zobaczyć kogoś, coś’ (SWJP, t. V, 47).
} 
smutek, tęsknotę, rozgoryczenie, zmartwienie, wskazywane przez rzeczownik pociesze$n i e^{32} \mathrm{w}$ wyrażeniu nagroda pocieszenia ${ }^{33}$.

W liryku Niepewność znajdujemy ambiwalentne przeżycia związane z uczuciem miłości: nie znosisz i pożądasz (P, 18).

Igraszkom miłosnym zakochanych towarzyszy uczucie wstydu, przeniesione z osób na rzeczy, stąd zawstydzone ubrania / leża w kacie (N, 4).

\section{Nazywanie osób uczestniczących w miłości, kochanków}

By mogło zaistnieć uczucie miłości, musi być ten/ta, który/która czuje, oraz obiekt uczuć. W wypadku liryki miłosnej najczęściej używanymi leksemami nazywającym osoby darzące się miłością są kochanek ${ }^{34} /$ kochanka $^{35}$ / kochankowie. W omawianych wierszach poetka ani razu nie użyła tych leksemów, odnotować należy niewielką liczbę synonimów (np. rzeczownik kochanie). Zarówno nadawca uczucia, jak i odbiorca są obecni poprzez szereg wskaźników gramatycznych, przede wszystkich poprzez obecność zaimków osobowych, dzierżawczych oraz odpowiednich form werbalnych w 1. lub 2. os. lp. lub 1 os. $1 \mathrm{~m}$.

\section{1. 'Ten, kogo kocham, kochany, odbiorca uczucia'}

Jego obecność jest implikowana poprzez:

a) rzeczownik kochanie ( $N, 28)$;

b) zaimek dzierżawczy twój: moje bogactwo / jest / w twoich rękach (M, 16), szukać / twoich / ust / rąk (M, 13);

c) zaimek osobowy ty: $\boldsymbol{T} \boldsymbol{y}(\mathrm{N}, 3 ; \mathrm{N}, 12 ; \mathrm{N}, 14 ; \mathrm{N}, 15 ; \mathrm{N}, 21 ; \mathrm{N}, 28)$, jestem / z toba / a jak cię / nie ma / szukam / siebie (M, 9), Tobą/toba (N, 32; M, 3), szukać [...] ciebie (M, 13), $\boldsymbol{C i}(\mathrm{N}, 14 ; \mathrm{N}, 21 ; \mathrm{N}, 28 ; \mathrm{N}, 25)$, jakby $\boldsymbol{C i e ̨ ~ ( N , ~ 1 5 ; ~ N , ~ 2 3 ; ~ N , ~ 3 0 ) ; ~}$

d) zaimek nieokreślony ktoś: ktoś / chciał mnie wrzucić do ognia / uciekłam (N, 27), ktoś / kto nie spat dziś jeszcze (N, 31);

e) liczebnik ósmy: jest / siedem / cudów / świata / założę się / że widziałam / ósmy $(\mathrm{M}, 5)$;

f) liczebnik jeden (M, 15);

\footnotetext{
${ }^{32}$ Pocieszenie 'od czas. pocieszyć; znajdować pociechę, nabierać otuchy, przestawać się smucić, martwić' (SWJP, t. III, 358).

${ }^{33}$ Nagroda pocieszenia 'nagroda przeznaczona dla uczestników rywalizacji, konkursu, którzy nie zdobyli głównych nagród' (SWJP, t. III, 18).

${ }^{34}$ Kochanek 'mężczyzna związany uczuciowo z kobietą, kochający ją, utrzymujący z nią kontakty seksualne bez zawierania związku małżeńskiego' (SWJP, t. II, 232).

${ }^{35}$ Kochany 'drogi, miły, darzony miłością’ (SWJP, t. II, 232).
} 
g) formy werbalne 2. os. 1p.: tu byteś (N, 15), dríysz (N, 11), dotykasz ( $\mathrm{N}, 11)$, jesteś ( $\mathrm{P}, 9 ; \mathrm{P}, 18 ; \mathrm{N}, 3 ; \mathrm{N}, 11 ; \mathrm{N}, 21)$, masz ( $\mathrm{P}, 18)$, mieszkasz $(\mathrm{M}, 10)$, możesz $(\mathrm{N}, 15)$, mów $(\mathrm{N}, 31)$, mówiteś $(\mathrm{P}, 6)$, nie mów $(\mathrm{N}, 31)$, nie pozwól $(\mathrm{N}, 33)$, nie rozmawiateś / o motylach $(\mathrm{N}, 23)$, kochanie / szkoda że mnie nie styszysz (N, 28), nie zmienisz ( $\mathrm{P}, 18)$, odmierzyleś (N, 32), przywołujesz moje imię (N, 24), się opamiętasz (N, 30), spójrz $(\mathrm{N}, 26)$, tańczyleś $(\mathrm{P}, 6)$, toniesz $(\mathrm{N}, 24),[\mathrm{Ty}]$ / wiedzialeś $(\mathrm{N}, 15)$, wyczerpateś limit słów $(\mathrm{N}, 21)$, wybacz $(\mathrm{P}, 6)$, je wymawiasz $(\mathrm{N}, 24)$, zapomniałeś $(\mathrm{N}, 14)$, zebrateś $(\mathrm{P}, 6)$, zmierzasz $(\mathrm{P}, 18),[\mathrm{Ty}]$ / zapalisz / papierosa $(\mathrm{N}, 14)$;

h) metonimię postuszne ręce / nie stawiaty oporu $(\mathrm{N}, 31)$.

W liryku ***tyle Trochanowska określa ukochanego liczebnikiem jeden $\mathrm{z}$ dookreśleniem tylko, choć zaznaczyć należy, iż w procesie irradiacji semantycznej ${ }^{36}$ odnosi się on do motyla - metaforycznego zastępczego obrazu ukochanego. Upodobanie do przedstawiania kochanków jako ciem i motyli znajdujemy w erotykach epok wcześniejszych. Z badań Anety Wysockiej wynika, iż w twórczości polskiej Safony te pierwsze występują w kontekście uczucia nieszczęśliwego, takiego, które rani kobietę i niszczy ją. Motyle zaś służą do zobrazowania albo flirtu, albo niespełnienia ze względu na fizyczny bądź psychiczny dystans dzielący kochanków. W twórczości Marii Pawlikowskiej-Jasnorzewskiej „[z]askakiwać może też doniosłość rodzaju gramatycznego rzeczowników motyl i ćma, który wpływa na semantykę większości utworów - motyle zazwyczaj obrazują mężczyzn i ich zachowania, ćmy zaś - sytuacje, w jakich znalazły się kobiety"37. Zdaniem Anety Wysockiej motyl winien być atrybutem płci żeńskiej, gdyż ,pozostaje w zgodzie ze stereotypem, że kobieta i motyl są ucieleśnieniem piękna - delikatnego, barwnego i ulotnego" "38. Zarówno w lirykach Pawlikowskiej, jak i Trochanowskiej motyle to metaforyczne obrazy mężczyzn, co jest zgodne z tradycją poetycką, według której motyl symbolizował mężczyznę niestałego w uczuciach, płochego, wietrznika, zmiennika. Już u Franciszka D. Kniaźnina czytamy: Różnie skrzydełka kołysał, już jemu i łąk niestało; wszystkie kwiatki powysysał. Motylu, jeszcze ci mało? (O motylu 1-4, F.D. Kniaźnin) ${ }^{39}$.

Z powyżej przedstawionego repertuaru wskaźników językowych kreujących wizerunek kochanka, odbiorcy uczucia, wyłania się obraz istoty, której atrybutami czyni Trochanowska usta i ręce; atrakcyjnej fizycznie, stąd porównanie do ósmego cudu świata.

\footnotetext{
36 „Polega ona [irradiacja semantyczna] na wytworzeniu się pola semantycznego, często metaforycznego, z określonym ogniskiem zmian znaczeniowych, zachodzących w danym tekście”. Teresa Skubalanka, „O pojęciu irradiacji semantycznej i jego przydatności dla opisu magicznych funkcji mowy”, w: Studia o metaforze, red. Michał Głowiński, Aleksandra Okopień-Sławińska, t. 2 (Wrocław: Ossolineum. Wydawnictwo Polskiej Akademii Nauk, 1983), 182. Por. Tomasz Mika, Agnieszka Krygier, „Irradiacja semantyczna metafor w poezji Zbigniewa Herberta", Synchroniczne i diachroniczne aspekty badań polszczyzny, 2 (1995): 293-303.

37 Aneta Wysocka, „Motyle i ćmy w poezji Marii Pawlikowskiej-Jasnorzewskiej”, Język Artystyczny, 14 (2010): 138.

38 Tamże, 127-140.

${ }^{39}$ Cyt. za: Kopaliński, Stownik symboli, 235.
} 
Podkreślić należy, iż leksemy usta i ręce dookreślone zaimkiem twoje (twoje ręce czy twoje usta) to metonimiczne synonimy nazwy kochanek.

\section{2. 'Ta, która kocha, nadawca uczucia'}

Jej obecność jest zaznaczona poprzez:

a) formę 1. os. 1p. form werbalnych: będe (N, 32), dotykam: prawie dotykam obłoków (N, 15), idę, zostaję: i choć / ide już / to jednak / zostaję (M, 9), jestem (jestem / z toba M, 9; N, 32), mam: mam sznur peret / z rosy (M, 16), mam wrażenie (N, 24), tak dużo / mam Ci do powiedzenia (N, 28), myślę (N, 32), nie moge (N, 30; $\mathrm{P}, 6)$, tak dawno / ze nie pamiętam / Cię prawie $(\mathrm{N}, 23)$, nie potrafię $(\mathrm{N}, 24)$, [ja] nie wiem $(\mathrm{N}, 15)$, niostam $(\mathrm{N}, 14)$, pędzę / doganiam $(\mathrm{M}, 3)$, podpale / niepokoje $(\mathrm{N}, 14)$, rzucam $(\mathrm{N}, 11)$, stapam $(\mathrm{N}, 11)$, szlam obok $(\mathrm{N}, 15)$, szukam: a jak cię / nie ma / szukam / siebie (M, 9), widziałam / ósmy $(\mathrm{M}, 5),[\mathrm{ja}]$ / wiem $(\mathrm{N}, 15)$, wracam $(\mathrm{N}, 11)$, wypowiem $(\mathrm{N}, 30)$, wyszłam z Twoich snów $(\mathrm{N}, 15)$, zawróciłam $(\mathrm{N}, 14)$, zeszłam dziś / z tąki / na szosę (M, 15);

b) zaimek dzierżawczy mój: moje bogactwo (M, 16), moje imię (N, 24), moja gtowa $(\mathrm{M}, 15)$, dotykasz mych ust $(\mathrm{N}, 11)$;

c) zaimek zwrotny siebie (M, 9);

d) zaimek osobowy ja: ja $(\mathrm{N}, 3 ; \mathrm{N}, 12 ; \mathrm{N}, 14 ; \mathrm{N}, 15 ; \mathrm{N}, 21 ; \mathrm{N}, 28), \boldsymbol{m i}(\mathrm{P}, 18)$, deszcz / odświeżyt mi pamięć / zmieszany ze tzami (N, 25), ze mna (P, 6; P, 9; N, 11); mnie ( $\mathrm{P}, 18 ; \mathrm{N}, 27 ; \mathrm{N}, 28 ;$ do mnie N, 31, chciał mnie wrzucić do ognia / uciekłam N, 27).

Osoba kochająca, nadawca uczucia, jest nakreślona w sposób szkicowy, bez ujawniania szczegółów zarówno fizycznych, jak i osobowościowych; jawi się jako byt dynamiczny, co oddają formy werbalne (jestem, szukam, idę, zostaję, pędzę, doganiam), posiadający aspekt fizyczny (głowa, perty, usta: znów / dotykasz mych ust N, 11). Formy werbalne ujawniają płeć żeńską nadawcy uczucia, podobnie jak zaimek wskazujący $t a$. U łemkowskiej poetki proces ustatkowania się osoby kochającej i wybór monogamicznego związku jest zobrazowany metaforycznie jako zejście z łąki pełnej kuszących motyli 'metafora mężczyzn niestałych w uczuciach' na szosę:

$$
\begin{aligned}
& \text { niedomówienia } \\
& \text { mamy już } \\
& \text { za soba } \\
& \text { dlatego } \\
& \text { zeszłam dziś } \\
& \text { z łąki } \\
& \text { na szosę }(\mathrm{M}, 15)
\end{aligned}
$$

Raz znajdujemy nazwę peryfrastyczną ta której nie ma $(\mathrm{P}, 8)$ oraz nazwę synonimiczną jedyna $(\mathrm{P}, 8)$. 


\subsection{Kochankowie}

Wskaźnikiem obecności kochanków w omawianych lirykach nie są sygnały leksykalne, lecz:

a) zaimek dzierżawczy nasze w metaforycznym określeniu erotycznego kontaktu: $\boldsymbol{n a}$ sze zuchwalstwo (M, 7);

b) formy gramatyczne 1. os. lm. czasowników, zarówno w trybie orzekającym, jak i rozkazującym: bądźmy (P, 6), będziemy / mieć / siebie (M, 13), błądzimy (N, 30), budzimy się (M, 10), doszliśmy (N, 30), dziękujemy za gościnę Bogu $(\mathrm{N}, 4)$, jesteśmy sami ( $\mathrm{N}, 3 ; \mathrm{N}, 11)$, korzystamy / z uprzejmości ( $\mathrm{N}, 4)$, lecimy / na księżyc / plotkarze / zostana / na ziemi (M, 7), mamy: niedomówienia / mamy już / za soba (M, 15), mamy radość (N, 11), tak dawno / nie błądziliśmy / ulicami (N, 23), omijamy $(\mathrm{N}, 14)$, podzielimy $(\mathrm{N}, 14)$, podzielimy się $(\mathrm{N}, 30)$, spotkaliśmy $(\mathrm{M}, 14)$, trwajmy tak $(\mathrm{N}, 31)$, wyjęliśmy / stońce / z pomarańczy $(\mathrm{M}, 12)$, zamykamy $(\mathrm{N}, 14)$, zanieśliśmy $(\mathrm{N}, 33)$, zatańczymy noca / przy blasku świec $(\mathrm{N}, 4)$, zrobimy $(\mathrm{N}, 14)$;

c) formy gramatyczne 3. os. lm. czasowników: nie potrafili / zejść / na ziemię (N, 22), bezbtędnie / odnaleźli / siebie / błądząc (N, 22), pozostali / w ekstazie / zachwytu $(\mathrm{N}, 22)$

d) zaimek osobowy my: to tylko $\boldsymbol{m y}$ (N, 21), nam / naprzeciw (M, 14; N, 33), nami $(\mathrm{N}, 30)$, każde z nas / poszło do swego domu $(\mathrm{N}, 9)$;

e) zaimek osobowy oni: $\boldsymbol{C i}$ / którym kochać / nie wolno (N, 25);

f) liczebnik: tych dwoje (N, 9);

g) razem $(\mathrm{N}, 33)$

oraz wskaźnik stylistyczny - metonimia: ręce $(\mathrm{M}, 12)$, poplatane ręce $(\mathrm{N}, 11)$.

Kochanków unikających uczucia charakteryzuje poetka za pomocą epitetów pożałowania godni / i godni wspótczucia $(\mathrm{N}, 14)$ oraz zagubieni $(\mathrm{N}, 30)$,

Zarówno nadawca, jak i odbiorca uczucia nie są scharakteryzowani przez pryzmat walorów zewnętrznych. Końcówki fleksyjne form werbalnych oraz zaimki wskazujące są nośnikiem informacji, że nadawcą (osobą kochającą) jest kobieta, zaś odbiorcą (osobą kochaną) - mężczyzna.

Posługiwanie się przez poetkę zaimkami dzierżawczymi, osobowymi oraz odpowiednimi formami gramatycznymi, by implikować obecność osoby kochającej, kochanej i kochanków, stanowi zabieg przemyślany, dzięki temu opis sytuacji jednostkowej i niepowtarzalnej zyskuje wymiar zjawiska powszechnego, typowego.

\section{Wnioski}

Stefania Trochanowska w trzech tomikach wierszy: Motyle, Przedtem, teraz, potem, Nie pozwól uschnąc kwiatom opisuje w sposób lapidarny, wykorzystując niezbędną liczbę słów, 
dwa typy miłości: jako uczucie i jako zjawisko erotyczne. Uczucie miłości między osobami X a Y polega na pragnieniu bycia razem, dążeniu do bycia razem, w tym do zachowań erotycznych. Repertuar nazw oddających miłość jest dość ubogi, tworzony przez leksem miłość (6x), hiperonim uczucie (1x), synonimy niepełne grzech $(3 \mathrm{x})$, radość $(1 \mathrm{x})$, kochanie (1x), formy werbalne kochać (3x), czcić, bezcześcić (1x), figury stylistyczne, w tym peryfrazę sprawa uczuciowa $(1 \mathrm{x})$, metonimiczną peryfrazę upadek $i$ uniesienie, metaforę szukać lata $w$ zimie i grupy werbalne mieć siebie, być z kimś, odnaleźć siebie. Miłość nie jest dookreślana epitetami, ale jawi się jako wartość dynamiczna, zmienna w czasie, ulegająca ciągłemu procesowi doskonalenia.

Fizycznym objawem uczucia czyni poetka rumieniec, poza tym dreszcze, drżenie, thumiony oddech, nostalgię, brak apetytu i bezsenność.

Działania i zachowania związane z miłością oddają liczne czasowniki, np. szukać, czekać, wierzyć, zostawać, trzymać się. Tylko raz poetka nazywa przeżycia-doznania osoby kochającej z udziałem czasownika tęsknić oraz podkreśla wstyd - zawstydzone ubrania.

Kreację uczucia dopełniają portrety osób kochających. Podkreślić należy, iż sygnałem ich obecności są wskaźniki językowe w postaci form zaimków dzierżawczych i osobowych oraz form werbalnych 1 . os. lp., 2. os. lp. oraz 1. i 3. os. 1m., dzięki czemu opisy sytuacji jednostkowych i niepowtarzalnych zyskują wymiar uniwersum.

Trochanowska, zgodnie z tradycją poetycką, by opisać uczucie miłości, sięga po figury stylistyczne, pojawia się metaforyka z pola ognia (symbolizowanego przez lato M, 12, grupę werbalną ogrzać ręce M, 12, słońce M, 12, wulkan N, 15), dojrzewania czy obrazowania uczucia poprzez odwołanie się do zmysłu smaku ( $i$ miłość / dojrzewa / nabierając / smaku / rajskich / owoców M, 13). Figury stylistyczne, w tym metafory, pozwoliły poetce z jednej strony zminimalizować liczbę słów, jednocześnie otwierając wiele płaszczyzn interpretacyjnych, a z drugiej zobrazować za pomocą wrażeń zmysłowych (np. wzroku, smaku, dotyku) zjawisko niefizyczne. Trochanowska nie stosuje rekwizytów miłosnych występujących zarówno w podniosłym stylu poezji miłosnej, jak i w erotyku ludowym. U łemkowskiej poetki nie znajdujemy zatem strzał czy Kupidynowej pochodni.

Leksyka w omawianych wierszach w przeważającej mierze nie odbiega od normy języka ogólnego, zaś figury stylistyczne stosowane są z umiarem. Poetka używa słów charakterystycznych dla przeciętnego użytkownika języka polskiego, poświadczonych w Słowniku języka polskiego Mieczysława Szymczaka czy Słowniku współczesnego języka polskiego Bogusława Dunaja, bez dodatkowej kwalifikacji.

Jej przekaz ma charakter ponadnarodowy, wiersze napisane są w języku polskim, a więc projektowanym odbiorcą jest zarówno ludność polska, jak i łemkowska doskonale znająca polszczyznę. W całym tomiku wręcz niezauważalne są wskaźniki językowo-stylistyczne świadczące o łemkowskiej narodowości poetki. Miłość traktuje ona bowiem jak uczucie uniwersalne, przynależne każdemu człowiekowi, bez względu na narodowość. 


\section{Bibliografia}

\section{Źródla}

Trochanowska, Stefania. Motyle. Warszawa: Zjednoczenie Łemków, 1994.

Trochanowska, Stefania. Nie pozwól uschnąć kwiatom. Kraków: OL Kraków, wydane nakładem autorki, 1991.

Trochanowska, Stefania. Potem, teraz, przedtem. Nowy Sącz: Sądecka Oficyna Wydawnicza Wojewódzkiego Ośrodka Kultury w Nowym Sączu, 1984.

Bartmiński, Jerzy. „Jaś koniki poit. Uwagi o stylu erotyku ludowego”. Teksty, 2 (1974).

Bieńkowska, Danuta. „Między konwenansami a autentyzmem uczuć, czyli Reymontowska pieśń na cześć miłości”. W: Ścieżkami pięknej polszczyzny. Księga jubileuszowa dedykowana Profesor Mirosławie Białoskórskiej z okazji 65-lecia urodzin i 45-lecia pracy zawodowej, red. Leonarda Mariak, Adrianna Seniów. Szczecin: volumina.pl, 2011: 29-38.

Duć-Fajfer, Helena. „Literatura łemkowska drugiej połowy dziewiętnastego i początku dwudziestego wieku". Prace Komisji Wschodnioeuropejskiej PAU, VII (2001).

Duć-Fajfer, Helena. „Literatura łemkowska - zagadnienia badawcze”. Prace Komisji Wschodnioeuropejskiej PAU, V (1997): 87-98.

Duć-Fajfer, Helena. „Mniejszościowa wizja miejsca swej grupy w społeczeństwie polskim na podstawie twórczości literackiej Łemków". Przegląd Polonijny, 3 (1998): 137-157.

Duć-Fajfer, Helena. Pomiędzy bukwa a litera. Współczesna literatura mniejszości białoruskiej, ukraińskiej i łemkowskiej w Polsce. Kraków: Wydawnictwo Uniwersytetu Jagiellońskiego, 2012.

Dunaj, Bogusław, red. Słownik współczesnego języka polskiego. T. I-V. Kraków: Wydawnictwo SMS, 2000.

Kopaliński, Władysław. Słownik symboli. Warszawa: Oficyna Wydawnicza RYTM, 2001.

Mika, Tomasz, Agnieszka Krygier. „Irradiacja semantyczna metafor w poezji Zbigniewa Herberta”. Synchroniczne i diachroniczne aspekty badań polszczyzny, 2 (1995): 293-303.

Nowakowska-Kempna, Iwona. Konceptualizacja uczuć w języku polskim. Warszawa: Wydawnictwo SORUS, 1995.

Osiecka, Agnieszka. Najpiękniejsze wiersze i piosenki. Warszawa: Prószyński i S-ka, 2016.

Ożóg, Kazimierz. „Leksem miłość. Rozważania semantyczne i kulturowe”. W: Od miłości do nienawiści. Językowe mechanizmy kreowania emocji, red. Wioletta Kochmańska, Bożena Taras. Rzeszów: Wydawnictwo Uniwersytetu Rzeszowskiego, 2010, 9-19.

Rychter, Joanna, „Boże... / czemu nas opuściteś - odwołania religijne w tomie wierszy $Z$ ziemi do nieba Władysława Grabana”. Poznańskie Studia Polonistyczne. Seria Językoznawcza 25 (2018), 45: 167180 .

Rychter, Joanna. „[K]orzeni szukam pradziadów / co oplataja trzewia ziemi - językowa kreacja małej ojczyzny w tomiku Z ziemi do nieba Władysława Grabana”. Studia Językoznawcze. Synchroniczne i diachroniczne aspekty badań polszczyzny, 17 (2018): 271-289.

Siatkowski, Zbigniew. „Współczesna poezja Łemków - formowanie się pokolenia literackiego”. Загородa, 2/3 (1994): 48-54.

Skorupka, Stanisław. Stownik frazeologiczny języka polskiego. T. I. Warszawa: Wiedza Powszechna, 1967.

Skubalanka, Teresa. „O pojęciu irradiacji semantycznej i jego przydatności dla opisu magicznych funkcji mowy". W: Studia o metaforze, red. Michał Głowiński, Aleksandra Okopień-Sławińska. T. 2. Wrocław: Ossolineum. Wydawnictwo Polskiej Akademii Nauk, 1983.

Skubalanka, Teresa. Stownictwo poezji miłosnej J. Stowackiego na tle tradycji. Toruń: Wydawnictwo Uniwersytetu Mikołaja Kopernika, 1966. 
Sławski, Franciszek. „Miły, miłość”. Język Polski 80 (2000), 1-2: 1-9.

Szadura, Joanna. „Dlaczego wrona jest czarna?”. Twórczość Ludowa, 2/3 (1995): 20-24.

Szymczak, Mieczysław. Słownik języka polskiego. T. I-III. Warszawa: PWN, 1983-1985.

Wysocka, Aneta. „Motyle i ćmy w poezji Marii Pawlikowskiej-Jasnorzewskiej”. Język Artystyczny, 14 (2010): 127-140.

[R]ozsadek / wyszedt nam / naprzeciw / szkoda / że nie / spotkaliśmy go / po drodze językowa kreacja miłości w polskojęzycznych lirykach Stefanii Trochanowskiej

Streszczenie

Celem artykułu jest charakterystyka środków językowo-stylistycznych zastosowanych przez Stefanię Trochanowską w polskojęzycznych tomikach poezji Potem, teraz, przedtem, Motyle, Nie pozwól uschnać kwiatom do wykreowania przewodniego uczucia miłości. Materiał analityczny zaprezentowano według propozycji badawczej Iwony Nowakowskiej-Kempny. Przeprowadzone badania wykazały, że łemkowska poetka opisuje w sposób lapidarny, wykorzystując niezbędną liczbę słów, dwa typy miłości: jako uczucie i jako zjawisko erotyczne. Miłość traktuje ona bowiem jak uczucie uniwersalne, przynależne każdemu człowiekowi, bez względu na narodowość.

[R]ozsądek / wyszedt nam / naprzeciw / szkoda / że nie / spotkaliśmy go / po drodze [Reason went out to find us / it is a pity we did not meet it] - Linguistic creation of love in the Polish-language lyrics by Stefania Trochanowska

Su m m ary

The article depicts the linguistic and stylistic means used by Stefania Trochanowska in her Polish-language volumes of poetry Potem, teraz, przedtem, Motyle and Nie pozwól uschnać kwiatom in order to create the leading emotion of love. The analysed material is presented according to the suggestion made by Iwona Nowakowska-Kempna. The research has revealed that the Lemko poetess describes two types of love - as a feeling and as an erotic phenomenon - using the necessary number of words in a succinct way. She treats love as a universal feeling, typical of every human being, irrespective of their nationality.

Cytowanie

Rychter, Joanna. [R]ozsądek / wyszedt nam / naprzeciw / szkoda / że nie / spotkaliśmy go / po drodzejęzykowa kreacja miłości w polskojęzycznych lirykach Stefanii Trochanowskiej. Studia Językoznawcze. Synchroniczne i diachroniczne aspekty badań polszczyzny 18 (2019): 125-141. DOI: 10.18276/ sj.2019.18-09. 